\title{
Is an Increase in Serum Magnesium One of the Causes of Cardiovascular Events Reduction in the EMPA-REG OUTCOME Study?
}

\author{
Tatsuo Yanagawa
}

\section{To the Editor}

The EMPA-REG OUTCOME study reported that a sodium glucose cotransporter-2 (SGLT2) inhibitor empagliflozin suppresses cardiovascular (CV) events in patients with type 2 diabetes [1]. It is noteworthy in this study that a reduction in hospitalization due to heart failure and death from $\mathrm{CV}$ was observed soon after the start of treatment. This rapid effect is difficult to explain by the slow-acting beneficial effect of empagliflozin on glucose and lipid metabolism. Various hypotheses have been proposed, and the ketone body hypothesis and hematocrit hypothesis have attracted attention [2]. Both hypotheses are expected to be tested in the future.

Previous studies have reported that serum magnesium $(\mathrm{Mg})$ increased by $0.07-0.18 \mathrm{mEq} / \mathrm{L}$ after the start of treatment with SGLT2 inhibitors [3, 4]. The EMPA-REG OUTCOME study also showed that serum $\mathrm{Mg}$ increased from 1.7 to $1.8 \mathrm{mEq} / \mathrm{L}$ [1]. We paid attention to an increase in $\mathrm{Mg}$. $\mathrm{Mg}$ acts as a coenzyme for various metabolic enzymes, and magnesium deficiency is known to have a harmful effect on blood pressure and glucose metabolism. Ninety-nine percent of $\mathrm{Mg}$ is present within cells and only $1 \%$ is present outside cells. Hypomagnesemia is likely to reflect magnesium deficiency in the whole body, but even if $\mathrm{Mg}$ is within the normal range, $\mathrm{Mg}$ in the whole body could be deficient [5]. The risk of CV is known to be high in hypomagnesemia.

According to the Framingham Heart Study, hypomagnesemia is a risk factor for atrial fibrillation [6]. Del Gobbo et al reported that hypomagnesemia tends to cause premature ventricular contractions, particularly in diabetic patients [7]. In addition, animal experiments showed that hypomagnesemia caused reduced cardiac function [8]. Hypomagnesemia has also been reported to increase platelet aggregation thereby facilitating thrombus formation and to enhance coronary artery constriction thereby facilitating myocardial infarction [9].

Studies involving the general population have reported that

Manuscript accepted for publication March 24, 2017

Department of Medicine, Nerima General Hospital and Public Interest Incorporated Foundation, Tokyo Healthcare Foundation, Institute of Healthcare Quality Improvement, Tokyo, Japan. Email: tyana-mj@xj9.so-net.ne.jp

doi: https://doi.org/10.14740/jocmr3014w every $0.2 \mathrm{mmol} / \mathrm{L}$ increase in serum $\mathrm{Mg}$ reduces a risk of $\mathrm{CV}$ up to $30 \%$ [10]. In the EMPA-REG OUTCOME study, serum $\mathrm{Mg}$ increased $0.1 \mathrm{mEq} / \mathrm{L}(0.05 \mathrm{mmol} / \mathrm{L})$, and therefore about $7.5 \%$ of risk reduction would be expected. The $32 \%$ suppression of CV shown in the EMPA-REG OUTCOME study cannot be fully explained by an increase in Mg. However, the EMPA-REG OUTCOME study involved diabetic patients with a history of $\mathrm{CV}$, while many studies on the relationship between hypomagnesemia and death from $\mathrm{CV}$ involved the general population. The influence of $\mathrm{Mg}$ may be greater in diabetic patients with high risk of CV. I suggest that $\mathrm{Mg}$ increase after the SGLT2 treatment may be involved in the favorable cardiovascular events reduction; however, it has rarely been discussed. The mechanism of increasing serum Mg by SGLT2 inhibitors is unknown [3], but I think that the improvement of Mg deficiency in body tissues had a beneficial effect on the cardiovascular system.

\section{References}

1. Zinman B, Wanner C, Lachin JM, Fitchett D, Bluhmki E, Hantel S, Mattheus M, et al. Empagliflozin, Cardiovascular Outcomes, and Mortality in Type 2 Diabetes. N Engl J Med. 2015;373(22):2117-2128.

2. Ferrannini E, Mark M, Mayoux E. CV Protection in the EMPA-REG OUTCOME Trial: A "Thrifty Substrate" Hypothesis. Diabetes Care. 2016;39(7):1108-1114.

3. List JF, Woo V, Morales E, Tang W, Fiedorek FT. Sodium-glucose cotransport inhibition with dapagliflozin in type 2 diabetes. Diabetes Care. 2009;32(4):650-657.

4. Tang H, Zhang X, Zhang J, Li Y, Del Gobbo LC, Zhai $\mathrm{S}$, Song Y. Elevated serum magnesium associated with SGLT2 inhibitor use in type 2 diabetes patients: a metaanalysis of randomised controlled trials. Diabetologia. 2016;59(12):2546-2551.

5. Ayuk J, Gittoes NJ. Contemporary view of the clinical relevance of magnesium homeostasis. Ann Clin Biochem. 2014;51(Pt 2):179-188.

6. Khan AM, Lubitz SA, Sullivan LM, Sun JX, Levy D, Vasan RS, Magnani JW, et al. Low serum magnesium and the development of atrial fibrillation in the community: the Framingham Heart Study. Circulation. 2013;127(1):33-38.

7. Del Gobbo LC, Song Y, Poirier P, Dewailly E, Elin RJ, Egeland GM. Low serum magnesium concentrations are 
associated with a high prevalence of premature ventricular complexes in obese adults with type 2 diabetes. Cardiovasc Diabetol. 2012;11:23.

8. Kramer JH, Spurney C, Iantorno M, Tziros C, Mak IT, Tejero-Taldo MI, Chmielinska JJ, et al. Neurogenic inflammation and cardiac dysfunction due to hypomagnesemia. Am J Med Sci. 2009;338(1):22-27.
9. Grober U, Schmidt J, Kisters K. Magnesium in Prevention and Therapy. Nutrients. 2015;7(9):8199-8226.

10. Del Gobbo LC, Imamura F, Wu JH, de Oliveira Otto MC, Chiuve SE, Mozaffarian D. Circulating and dietary magnesium and risk of cardiovascular disease: a systematic review and meta-analysis of prospective studies. Am J Clin Nutr. 2013;98(1):160-173. 